"Towards a regional-global organizational model for leading research driven business schools. Findings from a longitudinal study in China, Europe and the USA from 2010 until 2016"

\begin{tabular}{|c|c|}
\hline AUTHORS & Carsten M. Syvertsen \\
\hline ARTICLE INFO & $\begin{array}{l}\text { Carsten M. Syvertsen (2017). Towards a regional-global organizational model for } \\
\text { leading research driven business schools. Findings from a longitudinal study in } \\
\text { China, Europe and the USA from } 2010 \text { until 2016. Problems and Perspectives in } \\
\text { Management, 15(2), 36-45. doi:10.21511/ppm.15(2).2017.03 }\end{array}$ \\
\hline DOI & http://dx.doi.org/10.21511/ppm.15(2).2017.03 \\
\hline RELEASED ON & Wednesday, 07 June 2017 \\
\hline RECEIVED ON & Wednesday, 01 February 2017 \\
\hline \multirow[t]{2}{*}{ ACCEPTED ON } & Wednesday, 22 February 2017 \\
\hline & $(\mathrm{ccc}) \mathrm{EY}$ \\
\hline LICENSE & $\begin{array}{l}\text { This work is licensed under a Creative Commons Attribution } 4.0 \text { International } \\
\text { License }\end{array}$ \\
\hline JOURNAL & "Problems and Perspectives in Management" \\
\hline ISSN PRINT & $1727-7051$ \\
\hline ISSN ONLINE & $1810-5467$ \\
\hline PUBLISHER & LLC “Consulting Publishing Company "Business Perspectives" \\
\hline FOUNDER & LLC "Consulting Publishing Company "Business Perspectives" \\
\hline
\end{tabular}

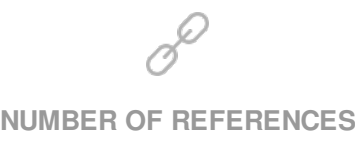

20
NUMBER OF FIGURES

0

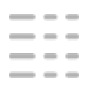

NUMBER OF TABLES

0

(C) The author(s) 2023. This publication is an open access article. 


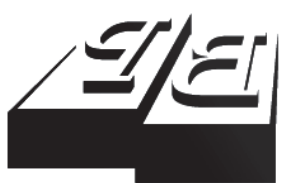

BUSINESS PERSPECTIVES

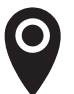

LLC "CPC "Business Perspectives" Hryhorii Skovoroda lane, 10, Sumy, 40022, Ukraine

www.businessperspectives.org

Received on: $1^{\text {st }}$ of February, 2017 Accepted on: 22 $2^{\text {nd }}$ of February, 2017

(C) Carsten M. Syvertsen, 2017

Carsten M. Syvertsen, Ph.D., Østfold University College, Norway; Visiting Researcher, Nordic Library of Athens, Greece.

\section{TOWARDS A REGIONAL-GLOBAL ORGANIZATIONAL MODEL FOR LEADING RESEARCH DRIVEN BUSINESS SCHOOLS. FINDINGS FROM A LONGITUDINAL STUDY IN CHINA, EUROPE AND THE USA FROM 2010 UNTIL 2016}

\begin{abstract}
The author introduces the regional-globalized organizational design model suited for business schools wishing to play leading roles in research in the global knowledge economy. Professors were interviewed and secondary sources were used in the collection process in the time period lasting from 2010 until 2016. Chaos theory is used to illustrate the relevance of the regional-global model analyzing six business schools in China, Europe and the USA. The research suggests that the sampled business schools have become more research-focused in the time period the research took place due to a more complex and turbulent business environment. This is particularly the case for the elite business schools Harvard Business School, IESE Business School and ChinaEurope Business School. The research suggests that tailor making of research efforts can help business schools in their struggle for success, using elements from the crafting society as a benchmark.
\end{abstract}

\section{Keywords business schools, regional-global organizational model, research focus, chaos theory, professors, tailor making of research, longitudinal study}

JEL Classification M20, I23, D83

\section{INTRODUCTION}

The problem statement is defined as to how business schools can win in the research race by focusing on regionalization in a globalized knowledge economy.

\section{PLAN FOR THE ARTICLE}

After analyzing the environments business schools are operating in, we introduce the regional-global model as the new organizational model for business schools playing leading roles in the global research economy. In order to illustrate the relevance of the organizational model, we use chaos theory as our theoretical framework. We focus on qualitative methods when interviewing professors from six leading business schools in China, Europe and the US. Secondary sources 
were also used in the data collection process. In the last part of the article, we discuss our findings of the research leading us to conclude that business schools can benefit from tailor making of research to the needs of business communities.

\section{A DIFFERENT ENVIRONMENT FOR BUSINESS SCHOOLS WITH A STRONGER FOCUS ON RESEARCH}

In 2005, Bennis and O'Toole (2005) wrote their classical article "How Business Schools Lost Their Way" in times with economic growth and optimism. The article can be regarded as a critical analysis of business schools not being able to satisfy the needs of the business community, paying too much attention to research almost as a value of itself. Pfeffer and Fong (2002) came with similar crucial comments. However, the argumentation of Bennis and O'Toole (2005) was much more direct and probably had a greater influence on business practices.

However, we believe that these comments are not as relevant as they once were. The article of Bennis and O'Toole (2005) was written in the hay days of economic growth where it is relatively easy to win support for the argument that business interests, almost per definition, should be given first priority. The economic crisis from 2008 up until today makes the business environment far more complex and turbulent, leading to a stronger focus on research, as we argue in this article.

In conflict with the writing of Bennis and O'Toole (2005), we consider research as critical for satisfying the needs of the business world operating increasingly in a globalized knowledge economy. This means that it can be necessary to disregard and even to overturn existing knowledge (Kuhn, 1970). Creating new knowledge requires theory building and conceptualization, experimentation and testing. In accordance with the Plato's school, the process of creating new knowledge also involves mistakes and dead ends (Lloyd, 1970).
Of undergraduate and graduate programs, undergraduate programs are the most important, as they are more research-focused on a strong focal point on philosophy involving a broad approach from the academic community (Kant, 1798, 1992). Graduate programs can be more applied in the sense that practical experience becomes more important. We are of the opinion that this argument is still relevant for studies of business schools (Syvertsen, 2008).

Studies of regionalization have become a popular research approach in the last decades. Specialized production, close cooperation, personal contact and a strong culture can lead to the necessary degree of flexibility in geographic limited areas (Piore and Sabel, 1984; Cappechi, 1990).

In a business world of regionalization, the value of craftwork becomes an asset in itself, as it helps business school to offer tailor-made research to carefully targeted market segments (i.e., Boynton, 2000). Our research suggests that the elite business schools Harvard Business School, IESE Business School and China-Europe Business School manage to tailor make services to the business community with respect to research, for example, in financial advices, energy, real estate and shipping. In many ways, the idea of crafting is in accordance with the classical idea of market differentiation where business schools try to gain a premium price with a service that the business community regards as unique (Porter, 1985).

In order to better understand regional dynamics, scholars within economics and innovation systems are of the opinion that innovation research can explore multi-dimensional process more in detail, especially on the global scale (Binz et al., 2014; Bunnell and Coe, 2001; Carlsson, 2006). The previous neglect of multi scale interrelatedness has been critized by Hassink et al. (2014) claiming that research has underestimated the complexity in business situations. We take a multiprocess approach by relating a regional approach to global challenges focusing on research using selected business schools as our empirical setting.

We built our reasoning based on research conducted by Drucker (1954), Handy (1992). Bartlett and Ghoshal (1995), and Syvertsen (2000), relating regionalization to operating on a small scale basis in a larger world. 
Globalization is the other factor pushing business schools to become more research-focused, serving the clients better and paying attention to increased complexity and turbulence in the business world. This leads to a change in competition in a dynamic and in dynamic and unambiguous way. (Brandley et al., 2000), where flexibility may be the only option (Sennett, 2002).

Europe and the USA are in a stage of flux due to lack of sufficient economic growth, with few signs of hopes in the horizon. China represents there other side of the coin with solid economic growth in the last decades leading to a great degree of interest from foreign investors having a positive effect on the operation of business schools.

\section{CLOSER DESCRIPTION OF OUR RESEARCH PROJECT ON BUSINESS SCHOOLS}

\subsection{Crisis at business schools}

"The crisis of business schools can be caused by an increased tension between the "base" and "superstructure", i.e. the ungoing work process and the structure established to manage them" (Mintzberg, 1989). By "base" we mean the business schools themselves, while by "superstructure" we mean "society", in our context regions, nations and the global world surrounding the business schools.

The Brexit decision of 23rd of June 2016 and the election of Donald Trump as US president in November 2016 are signs that the business landscapes are changing dramatically in Europe and the US, having effects on business education and the ways to conduct research at business schools.

How regional initiatives using research has been of minor interest seen from an organization design framework. This is also the case for studies of business schools. This lack of attention may to some degree be caused by "blind spots" in the traditional research approach, which, in general, focuses more on the use of linearity of stable system than studies of organizations in a stage of flux. It might, therefore, be argued that the role of a regional approach has been underestimated, particularly when regionalization is linked to globalization when conducting studies of business schools.

We introduce the regional-global model for how business schools might organize their activities well aware that theoretical models are often not sufficient to describe challenges faced by business schools. Business decisions can be regarded as a result of analytical analysis, as well as an element of art in times of great degree of change (Mintzberg, 1990, i.e., Steward, 1997).

\subsection{The use of theories in order to illustrate the regional-global organizational model}

The objective of research is to investigate relationships that repeat themselves (see Dubin, 1969), for example, the tendency of business schools to become more research-focused in a regionalized world of globalization, as we claim in this research project.

Kuhn (1972) introduced the concept of paradigm shift in order to focus on the changes in thinking that can take place over time. He defines a paradigm as a "scientific umbrella" that might unify theories that can be contradictory. We try to combine traditional theories of business practices with chaos theory in studies of business schools as a new area of research.

\subsection{The use of chaos theory}

In order to make the theoretical focus in accordance with the changing times of the business world, we focus on chaos theory in this research project. Chaos theory is flexible enough, so, it can be used with a certain degree of justification in studies of business schools.

Chaos theory pays attention to the fact that reality might be seen as a function of complex, dynamic, non-linear and unpredictable systems. Chaos describes a situation where a system is dislodged from its steady state condition by trigging events. It involves regrouping of elements of a given system from which a new order eventually emerges (Fitzgerald and Eijnatten, 1998). 
Complexity is related to the number and types of relations in a system (Rescher, 1998, p. 1). In case of a high degree of complexity, system behaviors will easily be perceived as being chaotic. The performance of a system is hard to explain based on how the various parts operate. From the moment of increased complexity in a system, subsequent expansion has a tendency to follow, i.e., complexity feeds on itself (Rescher, 1998, p. 6).

An edge of chaos exists when a system is in tenuous equilibrium. An analogy is borrowed from Waldrop (1992) explaining a pile of sand heaped on a table to the limit capacity. It implies a readiness for change, or "an edge of chaos" states in which the adhesive friction between the sand and grains are taxed to the limit of tolerability.

It is when a system is in a state of chaos that it is most vulnerable to the butterfly effect, which states that small causes can have large effects (Lorentz, 1963). This metaphor explains that a butterfly in Amazon can, of course theoretically, cause a swelling ripple that, in turn, can lead to a gigantic dust storm in Texas. Small effects can have dramatic effects on research efforts at "business schools, as we argue in this article.

\subsection{A flexible research approach}

Given the explorative way the research took place we had to use a flexible research approach. As the study processed, a similar process that outlined by Meyer et al. (1993, p. 68), whereby concepts and research methods were constantly rethought and updated following analysis and findings. Similarly, Hinings and Greenwood (1988, p. 99) argued that the researcher has to modify theoretical frameworks during the life of the project.

It has been recognized that the conventional research cycle conceptualization, design, measurement, analysis and reporting do not hold well in hyper-turbulent environments (Chiaburu, 2006), calling for more in-depth process research (Langley, 1999), as it is done in this research project.

An interpretive approach is regarded as suitable for the investigation of complex and poorly un- derstood phenomena (Dixon et al., 2007), since such an approach implies that the researcher's task is to "make sense of local actors' activities" (Soulsby and Clark, 2007; Astley and Zammuto, 1992).

\subsection{The choice of the sample}

We wish to include business schools in the sample with an excellent reputation in the business community with a focus on regionalization. We focus on research within the sampled business schools.

We included the Chinese business schools ChinaEurope Business School and Fudan University/ Fudan Business School, both located in Shanghai. In Europe, IESE Business School (Barcelona, Spain) and BI Norwegian School of Business (Oslo, Norway) were chosen. In the USA, Harvard Business School and the business school at the University of Wisconsin, Madison were elected after careful consideration and analysis.

Since the research on regionalization in a global context using business schools as the empirical setting is a new idea to our knowledge, we wished to get to grips as to how the business schools in the sample operate in general based on the concept of "thick descriptions" (Greetz, 1973) instead of aiming to go into details at this early research stage.

We chose the sample based on contacts with certain business schools, which can in this way be regarded as a convenience sample. This research is a result of dialogues with the professors for many decades, not only in questions regarding research, but also teaching and workshops in the academic community for decades.

In China, the author has contact with ChinaEurope Business School over many years. Contacts at Fudan University/Fudan Business School were established through the BI Norwegian Business School.

In Europe, the author has studied at both the BI Norwegian Business School and at IESE Business School in Barcelona. He has also studied at the business school of University of Wisconsin, Madison in the US. He came familiar with research con- 
ducted at Harvard Business School through doctoral studies at IESE Business School in Barcelona in the years from 1994 until the year 2000. In fact, IESE was founded in 1958 as a Harvard initiative, both business schools laying strong emphasis on the case method both in research and teaching.

\subsection{Data collection}

We collected data through secondary sources and through personal interviews. The primary source was semi-structured interviews with professors from each of the business schools in the sample. Personal contact was used as a method, combined with secondary sources gaining benefits of triangulation in the data collection process (Jick, 1979).

We used principles from inductive research trying to make sense out of unstructured data (Glaser and Strauss, 1967). This way of conducting the research gave us the possibility to get in contact with rich empirical data helping to shed light on business schools as complex organizations in the global research community (i.e., Miles and Huberman, 1994).

The interviews with the professors, all experienced men passed 50, took place in an informal atmosphere, not always focusing on research in the first parts of the interviews as it was planned. The professors were allowed to select their preferences for topics as the conversation developed. This way of interviewing made it possible to let the professors talk themselves "warm" about their area of expertise and move to the next area when appropriate, in accordance with the writing of McCracken (1988).

Six sets of questions were addressed when we met or were in contact with the professors in the time period from 2010 until 2016. The interviews took place as often as possible mainly using social media and e-mail. Personal contact was also used when it was possible.

The questions addressed were: (1) news in the research field of the business school where they work, (2) the research of the professors, i.e., publications, teaching, talks with business people, etc. (3) changes in the professors area of specialization, (4) regional, national and global changes in culture, economics and politics that can affect re- search at the given business school, (5) changes in how the concept of regionalization was perceived in the professors, (6) which effects in the concept of globalization has had on given business schools.

\subsection{Data analysis}

As is typical in inductive research, we analyzed the data by, first, building case studies and, then, comparing findings across cases in order to construct a conceptual framework (Eisenhardt, 1989).

By cases we mean the six business schools in the sample combining interviews with professors with secondary sources in the data collection. The main insights were gained through interviews of the professors.

As a first step, we entered transcribed responses into a database indexed by case and interview number. Through the use of interviews, we noted differences and similarities between cases, i.e., business schools, but waited with further analysis until we had completed all case write-ups to maintain and develop a solid logic.

Once the individual case studies were complete, we used cross-case analysis, relying on methods suggested by Eisenhardt (1989) in order to develop conceptual insights. Since the literature in regional challenges at business schools in a globalized world is limited, it was difficult to draw on similar research formats.

We created tables and graphs to facilitate further comparisons and differences between cases used as targets of analysis in order to develop a theoretical logic. We took several breaks during the data analysis in order to refresh our thinking. The whole process took almost six years, leading to the insights that follow.

\section{FINDINGS}

The findings can be regarded as preliminary due to little research conducted using the regional-global model as a way to study business schools. Business schools have to a little extent been studied using chaos theory as a framework making a study of this kind interesting. 


\subsection{Introduction of the regional- global organizational model in studies of business schools - a global empirical study}

In times with increased complexity and turbulence, we introduce the regional-global organizational model as a new model as to how business schools can organize their activities.

All six professors in the sample regarded the model as suitable for the challenges facing the business schools in the sample, however, a Norwegian professor found the regionalization "odd", as he needed a better definition of what a region is. Through dialogue in the research process, we managed to reach a workable consensus.

We base our findings on the financial crisis setting in fall 2008 lasting so far into 2017, with few signs of optimism in the horizon. The conclusions are also based on historical studies.

Both Europe and the USA are based upon a capitalist tradition of private initiative and decentralized organizational solutions from the first industrialized revolution up to modern times (Taylor, 1911; Chandler, 1962; Weber, 1991, 1905). When the economy goes down, as has been the case in the last decade, both the business world and business schools suffer. In such a business environment, our study suggests that business schools must be brave and ask why they exist at all, as Coase (1937) did in his proactive article. The answer is, of course, to put the customer first as a requirement to compete in an ever changing business environment by focusing on research combining theory with business practices.

The conclusions of the European and US business schools are not clear-cut. In the US, Harvard Business School has managed to recover from the economic crisis starting in fall 2008 due to a strong reputation in the business community both in the USA and internationally. The crisis hit the business school at the University of Wisconsin much harder due to less funding as a state university. The business school has, in times of trouble, moved back to its roots going regional. Wisconsin, known as one of the nation's leading dairy producers, particularly famous for production of cheese and bacon, became a natural domain for the business school. The contact with the large corporation Oscar Mayor has become even more important in the crisis years. Private financing of research project has also become more common. The green movement has influenced business practices in Wisconsin, leading to more research-based tourism also involving spiritual dimensions.

In Europe, the situation for IESE Business School in Barcelona (Spain) is similar to the situation for Harvard Business School with a strong research focus on the relationship with the business community. The research focus of IESE has become much stronger in the last decade, with a more global faculty and student body.

The BI Norwegian Business School was to a minor degree affected by the financial crisis from 2008 and later Norway as a nation was to a minor extent affected. High oil and gas prices had positive economic effects on the national economy when most other European countries suffered greatly in the economic recession. However, when the oil and gas prices fell dramatically in 2014, the Norwegian economy was under threat. It led to dramatic decreases in state incomes and negative by effected energy companies including shipping firms.

The BI Norwegian Business School has in the last decade become much more research-focused with a more global outlook, leading us to conclude that the school has managed to focus on research and building a good school known for their international publications.

Our research suggests that China represented the other side of the coin with a strong economic growth from 2010 until 2016, having positive effects on business schools. The Chinese economy has characteristics of the capitalist thinking, both historically and in the last decades with strong economic growth. The Chinese have a solid and proud history having business in the blood. Entrepreneurship becomes a requirement to win in the globalized knowledge economy, for example, in fire work and ship building, two industries where Chinese have been able to compete successfully globally since the 1970 s.

However, capitalism in China is of another nature than in Europe and in North America, as the Confucian school of thought can be regarded as a candidate to explain the Chinese business success, 
instead of looking at China through Western eyes that might lead to superficial insights.

Li (1991) holds that the main idea of Confucian managerial school is to control humans. Taking morality control as a core concept, Confucian managerial school not only admits external controlling standardized by etiquette, but also emphasizes internal factors of control. In the view of Confucianism, morality control enjoys a good controlling result as well.

In terms of modern business practices, Confucius focuses on the spiritual guide effect. Confucian business school is a concept that is very flexible compared to Western rigidity. It requests executives to introduce certain values into organizational members through their own conduct, making a conscious behavior coming from the heart, as a spiritual factor (Xianzhi et al., 2011).

The two sampled business schools have a quite different story in the last decades. China-Europe Business School can be regarded as a winner with strong research focus following the entrepreneurial opportunities both in China and globally carefully. Fudan Business School has traditionally followed political changes in China with a high degree of interest. In China today, a business approach can be regarded as more important leading us to conclude that ChinaEurope Business School is ahead of completion in China.

\subsection{A more research focused research focus in the sampled business schools}

Research is becoming more important in the sampled business schools in the time period from 2010 until 2016. The research project suggests that the business world needs more questions and more nontraditional answers to the challenges that they face The six professors in the sample are of the opinion that is regarded as a requirement to publish internationally to be a part of the elite in business education, with a focus on publications in top journals such as Administrative Science Quarterly and Harvard Business Review. International publications lead to the fact that it is easier to conduct research-based teaching, often welcomed by students, particularly at the graduate levels.
Our research suggests that Chinese business schools are quite different from their counterparts in Europe and the USA due to better economic times. As more money can be spent on research, it gives the Chinese business schools opportunities to take favorable positions in the globalized knowledge economy. This leads to the fact that more Chinese firms are used as cases in international publications and in teaching. Such a focus should, in our opinion, be in accordance with the objectives of the Chinese government wishing the country to play a major role globally both in business and politics.

Excellent business schools try to fill the gap as entrepreneurial partners in the business community. The research suggests that the elite business schools, namely Harvard Business School, IESE Business School and China-Europe Business School, manage to fill this gap to a great extent being well aware that craft is thriving in many regions where the skills, judgement and experience of people are creating unique value for customers.

Harvard Business School is serving the Boston's financial district with a great degree of intimacy in the relationships laying great emphasis on tailor making of research efforts. IESE Business School in Barcelona (Spain), building its foundations on principles from the Catholic Church, is well known for a strong research focus, both when serving national and international clients. We believe that it is wise strategy that will play off handsomely also in the future. China-European Business School is proud of the Chinese history and uses Chinese firms as cases in the research. With more confidence as a result of good economic times, we believe that this tendency will continue, leading to positive effects on research and on economic performance of the business school.

\subsection{Operationalization of the regional global model having a research focus on business schools}

Respondents mentioned that a focus on technology and leadership could lead to research success at business schools both in the short run and in the long run, using elements from the regional-global organizational model as a frame of reference. 


\subsubsection{Technology}

First class technology is necessary to be on top in research globally and also regionally. Good routines on operations are necessary to run a business school on a daily basis, illustrated through the daily life of the business schools in our sample.

Our findings suggest that change in routines through the use of technological knowledge is the main change agent in transformation processes, being more radical than simply stating that technology can make organizational practices more effective (Barney, 1986; Orlikowski, 2000; Szulanski, 2000).

This way of looking at technology means that changes can take place in the daily operation of business schools. To be more concrete, it means that technology can help business schools in their research efforts by making numerous small adjustments to facilitate technology implementation (Orlikowski, 2000).

\subsubsection{Leadership}

The business world is experiencing great changes calling for a need for strategizing the leadership role. This means that it is necessary to tailor make the leadership role in a more research-focused business environment much more global in na- ture than in the past, with a dual focus on regionalization, as it is argued in this research.

Leadership implementation often requires experimentation, using trial and error as means to find satisfactorily solutions (Thomke, 1998) in a world where it is often difficult to find optimal solutions (Mintzberg, 1990). This means that theory and practice must be seen as interrelated (Argyris and Schon, 1978; Schon, 1983) paying attention to the dual focus of business schools, trying to balance the two in order to serve the business community in the best possible way.

\subsection{Limitation of the research project}

At this early research stage, there are naturally a number of shortcomings when introducing the regional-global model of studies of business schools.

The sample is small involving six business schools, operating at three continents. Only six professors were interviewed, leading to a limited insight in spite of the fact that the conservations took place over a period of six years from 2010 until 2016. The professors interviewed are all men over 50 leading us to conclude that the danger of group thinking might exist (Janis, 1972). A more heterogeneous sample might have led to more conflicting and maybe also deeper conclusions.

\section{CONCLUSION}

We used six business schools located in China, Europe and the USA as our empirical setting as representatives of a dynamic, turbulent and changing knowledge economy. Our respondents were professors at six business schools giving us deep insights on the institutions they work for. In addition, secondary sources such as document analysis were used in order to investigate if the regional-globalized organizational model made sense in the sampled business firms.

Our problem statement was confirmed with certain modifications. Overall, the concept made sense for the business schools in the sample, as it was a new way of thinking on globalization issues. The use of the model must be regarded as gradual with a lot of trial and error on the way business schools choose to introduce it.

We believe that that it is the reason to believe that the complexity and the turbulence of the environment business schools operate in will increase in the future. In such environments, it can be argued that research will become more important.

In future publications on the regional-global model, using business schools as the empirical setting, more in-depth studies of the sampled schools can lead to more insights. A greater sample is welcome 
interviewing more professors, the administration, students, and, of course, executives from the business world. While our study is qualitative in nature, quantitative studies can shed new light on the operations of business schools.

Linking business schools to the ambidexterity organization is a candidate for future studies of business schools paying attention to the fact that research can aim at reaching the objectives both in the business community and as part of the larger political landscape.

\section{ACKNOWLEDGEMENT}

The author wishes to thank his children Alexander and Christina for the inspiration in writing the article. I am a very proud father.

\section{REFERENCES}

1. Argyris, C., and Schon, D. A. (1978). Organizational Learning. Addison-Wesley, Reading, MA.

2. Astley, W. G., and Zammuto, R. F. (1992). Organization Science, Managers and Language Games. Organization Science, 3(4), 443-460.

3. Barney, G. (1986). Technology as an occasion for structuring: Evidence from observations of CT scanners and the social order of radiology departments. Administrative Science Quarterly, 20, 160-176.

4. Barlett, C. A., and Ghoshal, S. (1988). Managing Across Borders: The Transnational Solution. Harvard Business School Press. Cambridge, Mass.

5. Barlett, C. A., and Ghoshal, S. (1995). Transnational Management: Text, Cases and Readings in Cross-Border Management ( $2^{\text {nd }}$ ed.). Irwin. Chicago.

6. Beech, N., and Johnson, P. (2005). Discourses of Disputed Identities in the Practice of Strategic Change. The Mayor, the Street-fighter and the Insider-out. Journal of Organizational Change Management, 18(1), 31-47.

7. Bennis, W., and O’Toole, J. (2005). How Business Schools Lost Their Way. Harvard Business Review, May, 1-20.

8. Binz, C. B. Truffer, and Coenen, L. (2014). Why space maters in technological innovation systems-
Mapping global knowledge dynamics of membrane bioreactor technology. Research Policy, 43, 138-155.

9. Boynton, A. (2000). Craft Networks. In P. Strebel (Ed.), Focused Energy: Mastering Bottom-Up Organization. John Wiley \& Sons, Chichester, England.

10. Bradkey, H. M., Erickson, Stephenson, C., and Williams, S. (2000). Myths at Work. Oxford Policy Press, Oxford, UK.

11. Brown, M. (1990). Defining stories in organizations: Characteristics and functions. In J. A. Anderson (Ed.), Communication yearbook, 13 (pp. 162-190). Newbury Park, CA: Sage.

12. Brown, M. H., and Krepes, G. L. (1993). Narrative analysis and organizational development. In Herndon, S. L., and Kreps, G. L. (Eds.), Qualitative research: Applications in organizational communication (pp. 47-62). Cresskill, NJ, Hampton Press.

13. Bunnel, T. G., and Coe, N. M. (2001). Spaces and scales of innovation. Progress in Human Geography, 25, 569-589.

14. Capeuchi, V. (1990). A history of flexible specialization and industrial districts in Emilia Romagna. In F. Pyke, G. Becattini and W. Sengenberger (Eds.), Industrial Districts and Inter- firm Co-operation in Italy. ILO publications, Geneve, Switzerland.

15. Carlsson, B. (2006). Internationalization of innovation systems: A survey of the literature. Research Policy, 35, 56-67.

16. Chandler, A. D. Jr. Strategy and Structure. MIT Press, Cambridge, Mass (USA).

17. Chiaburu, D. S. (2006). Managing organizational change in transition economics. Journal of Organizational Change Management, 19(6), 738-746.

18. D’Aveni, R. A. (1994). Hyper competition. Managing the Dynamics of Strategic Maneuvering. The Free Press, New York.

19. Coase, R. S. (1937). The Nature of the Firm. Economica, N.S., 4, 386405. Reprinted in G. J. Stigler and K. E. Boldings (Eds.), Readings in Price Theory (1952). Richard D. Irwin, Homewood, IL.

20. Dixon, S., Meyerm, K. E., and Day, M. (2007). Exploitation and Exploration Learning and the Development of Organizational Capabilities: A cross-case Analysis of the Russian Oil Industry. Human Relations, 60(10), 14931523.

21. Drucker, P. (1954). The Practice Management. Harper and Row, New York.

22. Dublin, R. (1969). Theory Building. Free Press, New York. 
23. Eisenhardt, K. E. (1989). Building theories from case study research. Academy of Management Review, 14(4), 532-550.

24. Emondson, A. C. (1999). Psychological safety and learning behavior in work teams. Administrative Science Quarterly, 44, 359-383.

25. Glaser, B. G., and Strauss, A. L. (1967). The Discovery of Grounded Theory: Strategies for Qualitative Research. Adline Publishing Company, NY.

26. Geertz, C. (1983). Local knowledge: Further essays in interpretive anthropology. Basic Books, New York.

27. Handy, C. (1992). Balancing corporate power: A new federalist paper. Harvard Business Review, Nov./Dec., 59-72.

28. Hassink, R., Klaerding, C., and Marques, P. (2014). Advancing evolutionary geography by engaged pluralism. Regional Studies, 48, 1295-1307.

29. Hayek, F. A. (1945). The use of knowledge in society. American Economic Review, 35(4), 519-530.

30. Hindings, C. R., and Greenwood, R. (1988). The Dynamics of Strategic Change. Basel Blackwell, Oxford.

31. Jick, T. D. (1979). Mixing qualitative and quantitative methods: Triangulation in action. Administrative Science Quarterly, 24(4), 602-611.

32. Janis, I. L. (1972). Victims of groupthink: A psychological study of foreign policy decisions and fiascos. Houghton-Mifflin, Boston.

33. Kant, I. $(1798,1992)$. The Conflict of Faculties. University of Nebraska Press, Nebraska.

34. Kreps, G.L, Ferndon, and Arnesson, P. (1993). The power of qualitative research to address organizational issues. In S. E. Herndon and G. L. Kreps (Eds.), Qualitative research: Application in organizational communication. Hampton Press, USA.

35. Kuhn, T. (1972). Scientific Paradigms. In B. Barnes (Ed.),
Sociology of Science. Penguin, Hamondworth (UK).

36. Langley, A. (1999). Strategies or Theorizing from Process Data. Academy of Management Review, 24(49), 691-710.

37. Li, H. (1991). Controlling directed by morals and controlling standardized by etiquette Controlling Theory of Confucian Managerial Philosophy. Confucius Study, 1991(4), 5-16 (Chinese).

38. March, J. G., and Simon, H. A. (1958). Organizations. John-Wiley and Sons, New York.

39. Meyer, A. D., J. B. Goes, and Brooks, G. R. (1993). Organizations Reachting to Hyper turbulence. In Huber, C. P. and Glink, W. H. (Eds.), Organizational Change and Redesign: Ideas and Insights for Improving Performance. Oxford University Press, Oxford.

40. Miles, M. B., and Huberman, A. M. (1994). Qualitative Data Analysis. Sage, Thousand Oaks, Cal.

41. Mintzberg, H. (1990). The design school: reconsidering the basic premises of strategic management. Strategic Management Journal, 11(3), 171-195.

42. Minzberg, H. (1989). Mintzberg on Management: Inside Our Strange World of Organizations. Free Press, New York.

43. Morowitz, H. (1993). Entropy and the Magic Flute. Oxford University Press, New York.

44. Orlikowski, W. J. (2000). Using technology and constitution structures: A practice lens for studying technology in organizations. Organization Science, 11, 404-428.

45. Peters, T., and N. Austin, N (1985). A passion for excellence. The leadership difference. Random House. New York.

46. Pfeffer, J., and Fong, C. T. (2002). The End of Business Schools? Less Success Meets the Eye. Academy of Management Learning and Education, 1(1), September, 21-32.

47. Piore, M., and Sabel, C. (1984). The Second Industrial Divide. Basic
Books, New York.

48. Porter, M. E. (1985). Competitive Advantage: Creating and Sustaining Superior Performance. The Free Press, New York.

49. Schon, D. A. (1983). The Reflective Practitioner. Basic Books, New York.

50. Sennett, R. (2002). A society of broken eggs, New Statesman, 17 December 2001-7 January 2002.

51. Soulsby, A., and Clark, E. (2007). Organization Theory and the Post-socialist Transformation: Contributions to Organizational Knowledge. Human Relations, 60(10), 1419-1442.

52. Stewart, T. A. (1997). Intellectual capital: The new wealth of organizations. Doubleday, London (UK).

53. Syvertsen, C. (2000). Towards the business federation in management consulting firms. Doctoral thesis, IESE Business School, University of Navarra, Barcelona.

54. Syvertsen, C. (2008). What is the future of business schools? European Business Review, 20(2), 142-151.

55. Taylor, F. W. (1911). The Principles of Scientific Management. Norton, New York.

56. Warren, B., and J. O'Toole (2005). How business schools lost their way. Harvard Business Review, May issue.

57. Weber, M. (1991/71905). The Protestant Ethics and the Spirit of Capitalism. Harper Collins Academy, New York.

58. Xianzhi, Z., Yuanyuan, L., and Yuting, W. (2011). Management Control Systems of Chinese Enterprises. Control and Management, Sonderheft, 47-52. 